\title{
SUSPENSION CULTURE OF ERYTHROCYTES IN THE ASSESSMENT OF THE DETERGENT FUNCTIONAL COMPONENT TOXICITY LEVEL
}

\author{
O.I. Yalovenko ${ }^{1}$, O.V. Raietska ${ }^{1}$, O.M. Holichenkov ${ }^{1}$, V.I. Liashenko ${ }^{1}$, O.M. Dugan ${ }^{2 *}$ \\ ${ }^{1}$ State Institution "O.M. Marzieiev Institute for Public Health", National Academy of Medical Sciences of Ukraine, Kyiv, Ukraine \\ ${ }^{2}$ Igor Sikorsky Kyiv Polytechnic Institute, Kyiv, Ukraine \\ *Corresponding author: odugan51@gmail.com
}

Received 20 May 2020; Accepted 15 July 2020

\begin{abstract}
Background. The study is devoted to the assessment of the cytotoxic properties of various surfactants by a method that is highly sensitive to identification of their negative effect on living mammalian cells.

Objective. The aim of the work is to carry out a comparative assessment of modern surfactants in terms of the degree of manifestation of cytotoxic properties.

Methods. The study of 10 surfactants was carried out with a new method for assessing the cytotoxic effect of agents based on surfactants, which is a modification of The RBC Hemolysis Test and Hemoglobin Denaturation Test. This method calculates the integral cytotoxicity index, which takes into account the data obtained by two tests. The following indicators were determined in the work: the percentage of hemoglobin denaturation in a $1 \%$ surfactant solution $(D, \%)$, the concentration of the surfactant solution at which hemolysis of $50 \%$ erythrocytes occurs $\left(\mathrm{H}_{50} \%\right)$, and the cytotoxicity coefficient $\left(C_{\mathrm{c}}\right.$, conv. un.) of surfactants which is calculated by the formula $C_{\mathrm{c}}=\mathrm{H}_{50} / D \cdot 10000$.

Results. According to the integral $C_{\mathrm{c}}$ indicator, the studied surfactants can be ranked according to the degree of toxicity reduction in the following order: sodium lauryl sulfate $(0.09)$ - sodium laurate sulfate $(0.13)-$ cocamidopropyl betaine $(0.27)$ - sodium salt of polyethoxysulfosuccinate $(0.27)$ - alkyldimethyl betaine $(1.07)$ disodium cocoamphodiacetate (1.99) - sodium salt n-palmethylglutamic acid (3.22) - cocoglucoside (27.86). Diethanolamides of coconut oil fatty acids and polyquaternium 7 in the studied concentration range (up to $1 \%$ ) did not show denaturation properties.

Conclusions. Studies have shown that surfactants significantly differ from each other by the level of the damaging effect, the most aggressive components were anionic and amphoteric surfactants, nonionic surfactants have a significantly lower cytotoxic effect (10 times). The results obtained should be taken into account when creating soft agents based on surfactants.
\end{abstract}

Keywords: denaturation of hemoglobin; hemolysis of erythrocytes; anionic surfactants; amphoteric surfactants; nonionic surfactants; toxicity; damaging action.

\section{Introduction}

The active use of various surfactants in the household chemicals and cosmetics, as well as the development of new original surfactants with different specific and structure-forming properties, necessitate a preclinical assessment of their toxicological profile $[1,2]$. Most often, when using surfactants, the calculation of the risk of toxic manifestations is based on the analysis of their chemical structure and the results of the experimental studies of their known analogues. Therefore, most of the available data on the safety of the surfactants are only predictions that cannot be used to compare their toxicological characteristics. Recent scientific publications indicate a prolonged dangerous effect of well-known surfactants of the detergents. It has been also experimentally demonstrated that in multicomponent formulations, these ingredients manifest the properties of enhancers that easily overcome the transdermal barrier. They penetrate through the horny layer into the deeper layers of the skin, interact with the proteins, changing the functional cells of the skin, increase the fluidity of lipid structures [3, 4]. The scientists have established that molecules of sodium lauryl sulfate penetrate to the epidermis, take root in its lipids, disrupt their synthesis and affect keratinocytes and corneocytes, resulting in increased transdermal water loss and perfusion of the epidermis, changed hydration of the horny layer and blood flow that cause the disorders of the skin barrier function [3-5]. That is, the surfactants are aggressive components of the detergents, and a degree of the manifestation of their damaging effects may be different. Therefore, it is relevant to conduct a comparative analysis of the cytotoxic properties of various surfactants by the methods that are the most sensitive ones to the detection of their negative effect on live mammalian cells. 
The goal of our work was to conduct a comparative assessment of modern surfactants by the degree of the manifestation of their toxic properties by the Method for the Assessment of Cytotoxic Effect of the Agents Based on Surfactants.

\section{Materials and methods}

Materials. Anionic surfactants: sodium lauryl sulfate, sodium laurate sulfate, sodium salt of polyethoxysulfosuccinate; amphoteric surfactants: disodium cocoamphodiacetate, alkyldimethylbetaine, cocamidopropylbetaine, sodium salt of n-palmethylglutamic acid; nonionic surfactants: cocoglucoside, diethanol amides of fatty acids of coconut oil.

Subjects. The short-term culture of guinea pig erythrocyte cells was prepared by technique [6].

Methods. The study was conducted according to our Method for the Assessment of the Cytotoxic Effect of the Agents Based on Surfactants, described in patent No. 28727 and scientific paper $[6,7]$. This method is a modification of the RBC Haemolysis Test and Haemoglobin Denaturation Test [6]. The authors of the method, applied in the research, propose to use a culture of short-term erythrocyte suspension as an in vitro test system for toxicity. This methodological approach includes the assessment of the hemolytic effect of the agent and the percentage of denaturation of oxyhemoglobin in the mammalian erythrocyte culture, i.e. makes possible to evaluate the effect of the surfactants on the integrity of the erythrocyte cytoplasmic membrane (by the percentage of hemolysis of erythrocytes) and cellular proteins (by the percentage of denaturation of oxyhemoglobin) in the experimental solution. Hemolysis and denaturation characterize different processes of the manifestation of irritating effect of the agents that can complement each other. Therefore, the two methods' study is performed in parallel and, when calculating the potential of cytotoxic action, takes into account the coefficient of cytotoxicity $\left(C_{\mathrm{c}}\right)$.

Evaluation of the effect of the surfactants on the integrity of hemoglobin (percentage of hemoglobin denaturation) was performed in several steps.

The first step: performance of 3 experiments in parallel: I experiment - cultivation of erythrocytes with the studied surfactant; II experiment cultivation of the erythrocytes with a substance with proven toxicity (positive control); III experiment - cultivation of the erythrocytes with water (negative control), followed by the determination of the fugat optical density of their culture fluid at the wavelengths of 540 and $575 \mathrm{~nm}$. The second step is to calculate the hemoglobin D denaturation coefficient according to the recommendations $[6,7]$.

The study of hemolytic properties of the surfactants was performed according to the method [6, 7].

Then we calculated the integral index - the cytotoxicity coefficient $\left(C_{\mathrm{c}}\right)$, which took into account the results of the experiments conducted by two methods. This integral index of cytotoxicity $C_{\mathrm{c}}$ is calculated by the formula $C_{\mathrm{c}}=\mathrm{H}_{50} / D \cdot 10000$ where $C_{\mathrm{c}}$ is the index of cytotoxicity (conventional unit); $\mathrm{H}_{50}$ is the index of erythrocytes' hemolysis (\%); $D$ is the percentage of hemoglobin denaturation (\%) $[6,7]$.

The studies carried out by this method have some limitations: they can not be used in the evaluation of dyed substances, insoluble ingredients, strong acids [7, 8]. If necessary, the proposed method can be used as an alternative one to the traditional methods for the determination of the skin irritation and effect on the mucous membrane of the eye, and as a method for the assessment of damaging effect level in the study of toxicity of the surfactants and agents based on them.

The obtained results were processed with the help of the traditional methods of variable statistics using the licensed computer programs Microsoft Excel and Statistica 10 [9].

\section{Results and discussion}

A surfactant is a multifunctional ingredient that provides, first of all, the effective action of synthetic detergents, dishwashing detergents, shampoos, shower gels, bath foams, liquid soaps, etc. In addition, the surfactants perform the structure-forming, emulsifying and thickening functions in the composition of household chemicals and cosmetics and are the enhancers for the biologically active additives. That is, the surfactants are practically an indispensable component for many cosmetic products and household chemicals, so the determination of the level of their toxicity is important for the creation of the formulations with a predicted lower level of damaging effect. Thus, a toxic effect of the surfactants on live cells is a prior indicator in the research program of the surfactant profiles.

For the comparative studies of cytotoxic effect, the surfactants were selected from the groups different by chemical structure and functional purpose. All of them are sold on the market in the form of stabilized aqueous solutions, their full composition and functional purpose are presented in Table 1.

The results of the study of hemoglobin denaturation process are presented in Table 2 . 
Table 1: Composition and functional purpose of stabilized solutions of surfactants chosen for study

\begin{tabular}{|c|c|c|}
\hline Surfactant & $\begin{array}{l}\text { Composition of stabilized solutions } \\
\text { of surfactants }\end{array}$ & $\begin{array}{l}\text { Functional purpose } \\
\text { of surfuctants [10] }\end{array}$ \\
\hline Sodium n-dodecyl sulfate & $100 \%$ sodium lauryl sulfate & $\begin{array}{l}\text { Main cleansing component, foaming } \\
\text { agent }\end{array}$ \\
\hline Sodium laurate sulfate & $\begin{array}{l}68-70 \% \text { aqueous solution of sodium } \\
\text { laurate sulfate }\end{array}$ & $\begin{array}{l}\text { Main cleansing component, foaming } \\
\text { agent }\end{array}$ \\
\hline $\begin{array}{l}\text { Sodium polyethoxysulfosuccinate } \\
\text { sodium }\end{array}$ & $\begin{array}{l}39-41 \% \text { aqueous solution of sodium } \\
\text { salt of polyethoxysulfosuccinate }\end{array}$ & $\begin{array}{l}\text { Main cleansing component, foaming } \\
\text { agent }\end{array}$ \\
\hline Cocoamidopropylbetaine & $30 \%$ cocamidopropylbetaine & $\begin{array}{l}\text { Main and auxiliary cleansing } \\
\text { component, foaming agent }\end{array}$ \\
\hline Disodium cocoamphodyacetate & $\begin{array}{l}37.5-39.5 \% \text { aqueous solution } \\
\text { of disodium cocoamphodyacetate, } \\
11-12 \% \text { sodium chloride }\end{array}$ & $\begin{array}{l}\text { Main and auxiliary cleansing } \\
\text { component, foaming agent }\end{array}$ \\
\hline Alkyldimethylbetaine & $\begin{array}{l}30 \% \text { aqueous solution } \\
\text { of alkyldimethylbetaine }\end{array}$ & $\begin{array}{l}\text { Main and auxiliary cleansing } \\
\text { component, foaming and thickening } \\
\text { agent }\end{array}$ \\
\hline $\begin{array}{l}\text { Sodium salt of n-palmityl glutamic } \\
\text { acid }\end{array}$ & $\begin{array}{l}25-30.5 \% \text { sodium salt } \\
\text { of n-palmityl glutamic acid, } \\
4-6 \% \text { sodium chloride }\end{array}$ & $\begin{array}{l}\text { Main and auxiliary cleansing } \\
\text { component, foaming agent }\end{array}$ \\
\hline Cocoglucoside & $\begin{array}{l}51-53 \% \text { aqueous solution } \\
\text { of cocoglucoside }\end{array}$ & $\begin{array}{l}\text { Cleansing component, foaming } \\
\text { agent }\end{array}$ \\
\hline $\begin{array}{l}\text { Diethanol amides of fatty acids } \\
\text { of coconut oil }\end{array}$ & $\begin{array}{l}100 \% \text { diethanolamides } \\
\text { of fatty acids of coconut oil }\end{array}$ & $\begin{array}{l}\text { Viscosity modifier and foaming } \\
\text { agent }\end{array}$ \\
\hline Polyquaternium 7 & $\begin{array}{l}40 \% \text { aqueous solution } \\
\text { of polyquaternium } 7\end{array}$ & Conditioning additive \\
\hline
\end{tabular}

Table 2: Percentage of hemoglobin denaturation in erythrocyte culture in vitro under the influence of surfactants

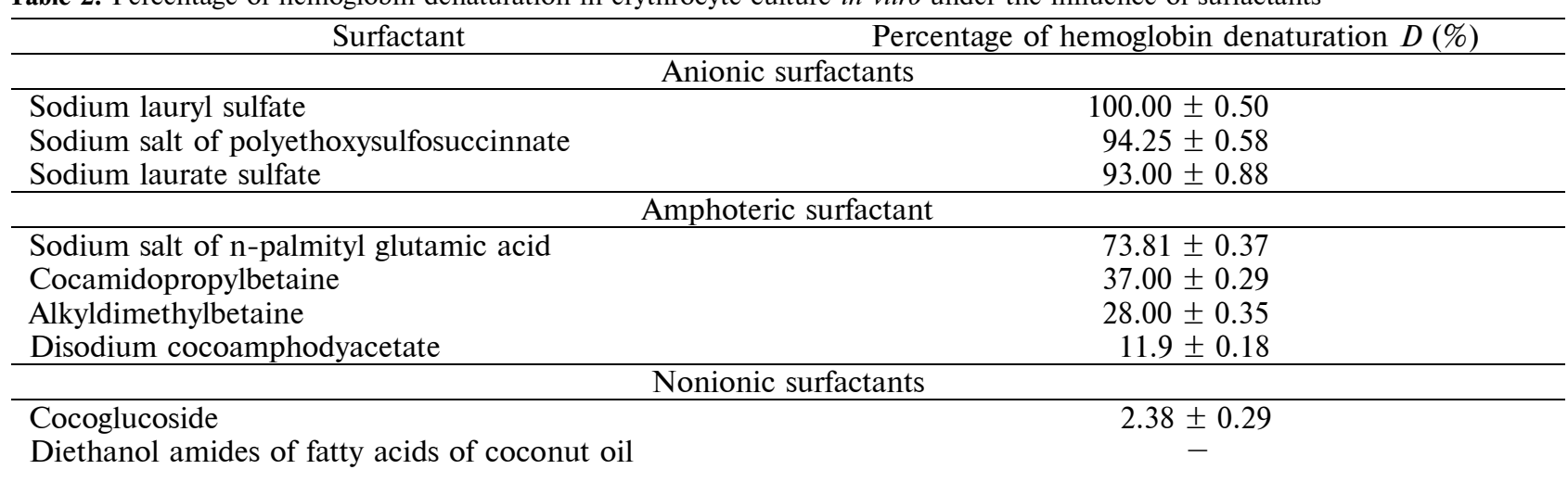

Polyquaternium 7

Cationic surfactants

The data above show that studied surfactants demonstrated a different ability to hemoglobin denaturation $(D)$ at a preset standard concentration of the solution. Thus, by the reduction of the degree of destructive power of the surfactants per hemoglobin molecule (percentage of hemoglobin denaturation), they can be placed in the following order: sodium lauryl sulfate (positive control) sodium salt of polyethoxysulfosuccinate - sodium laurate sulfate - sodium salt of n-palmitic glutamic acid - cocamidopropylbetaine - alkyldimethylbetaine - disodium cocoamphodiacetate - cocoglucoside. Others (diethanol amides of coconut oil fatty acids, polyquaternium 7) did not show their protein-destroying properties in the standard concentration chosen for the study. That is, according to this method, the most aggressive surfactants are anionic ones, because all studied anionic surfactants (sodium lauryl sulfate, sodium laurate sulfate, sodium salt of polyethoxysulfosuccinate) demonstrated a high denaturation ability from 93 to $100 \%$; amphoteric surfactants were less toxic ones - from 11.9 to $73.81 \%$; nonionic surfactants were "the softest" ones - without effect or up to $2.38 \%$; and cationic surfactants - polyquaternium 7 - without effect. 
Table 3: Concentrations of surfactant solution when hemolysis of in vitro erythrocyte culture takes place under the influence of surfactants

\begin{tabular}{|c|c|}
\hline Surfactant & $\begin{array}{l}\text { Concentrations of surfactant solution when hemolysis of } \\
50 \% \text { of erythrocytes, } \mathrm{H}_{50}(\%) \text {, takes place }\end{array}$ \\
\hline \multicolumn{2}{|c|}{ Anionic surfactants } \\
\hline Sodium lauryl sulfate & $0.00863 \pm 0.0000049$ \\
\hline Sodium laurate sulfate & $0.001123 \pm 0.0000009$ \\
\hline Sodium salt of polyethoxysulfosuccinate & $0.007343 \pm 0.0000123$ \\
\hline \multicolumn{2}{|c|}{ Amphoteric surfactant } \\
\hline Cocamidopropilbetaine & $0.000996 \pm 0.0000006$ \\
\hline Disodium cocoamphodiacetate & $0.002372 \pm 0.0000009$ \\
\hline Alkyl dimethylbetaine & $0.002989 \pm 0.0000024$ \\
\hline Sodium salt of n-palmityl glutamic acid & $0.023770 \pm 0.0000058$ \\
\hline \multicolumn{2}{|c|}{ Nonionic surfactants } \\
\hline Cocoglucoside & $0.006631 \pm 0.0000027$ \\
\hline Diethanol amides of fatty acids of coconut oil & $0.058888 \pm 0.0000012$ \\
\hline \multicolumn{2}{|c|}{ Cationic surfactants } \\
\hline
\end{tabular}

The study of hemolytic properties of the surfactants by means of the detection of the concentration of their solutions, when hemolysis of $50 \%$ of erythrocytes took place, (hemolysis of erythrocytes $-\mathrm{H}_{50}$ ), was performed in the range of concentrations from 0 to $0.1 \%$ that was limited by the method of determination. The obtained results are presented in Table 3.

The data presented in Table 3 show that the only polyquaternium did not have hemolytic activity in a given range of concentrations and it did not show a denaturation ability when adding into the culture of erythrocytes. Others can be placed by the degree of $\mathrm{H}_{50}$ increase, i.e. by the reduction of the toxicity, in such a way: sodium lauryl sulfate cocamidopropylbetaine - sodium laurate sulfate disodium cocoamphodiacetate - alkyldimethylbetaine - cocoglucoside - sodium salt of polyethoxysulfosuccinate - sodium salt of n-palmatylglutamic acid - diethanol amides of fatty acids of coconut oil.

The obtained data of the studies of cytotoxic effect of the surfactants by two methods differ slightly in the degree of toxicity. Thus, high hemolytic activity was demonstrated by both anionic surfactants (sodium lauryl sulfate, sodium laurate sulfate) and amphoteric surfactants (cocamidopropylbetaine and disodium cocoamphodiacetate, alkyldimethylbetaine), and when assessing the denaturation ability, the denaturation coefficient of cocamidopropylbetaine $(D-37 \%)$, alkyldimethylbetaine $(D-28 \%)$ and disodium cocoamphodiacetate $(D-$ $11.9 \%)$ was significantly smaller than of sodium salt of polyethoxysuccinate $(D-94.25 \%)$ and sodium salt of n-palmitylglutamic acid $(D-$ $73.81 \%)$. At the same time, by the hemolytic acti- vity, the sodium salt of polyethoxysulfosuccinate $(0.007343 \%)$ and the sodium salt of n-palmitylglutamic acid $(0.023770 \%)$ were "softer" than disodium cocoamphodiacetate $\left(\mathrm{H}_{50}-0.002372 \%\right)$, alkyldimethylbetaine $\left(\mathrm{H}_{50}-0.002989 \%\right)$, cocamidopropylbetaine $\left(\mathrm{H}_{50}-0.000996 \%\right)$ and cocoglucoside $\left(\mathrm{H}_{50}-0.006631 \%\right)$.

The analysis of study results shows that there is no always clear inverse relationship between the hemolysis rate of erythrocytes and the rate of denaturation ability (higher hemolysis rate - lower denaturation rate), it means that the effect on protein structures and cell membrane in different surfactants may take place by different mechanisms of the effect depending on the chemical structure of substances $[7,8]$.

Therefore, the integrated cytotoxicity index $C_{\mathrm{c}}$, which determines the degree of cytotoxic effect of surfactants, takes into account the results of two experiments.

At the absence of the process of hemoglobin denaturation in a preset surfactant solution, the coefficient $C_{\mathrm{c}}$ is not calculated and only the hemolytic activity of the agents is evaluated. The findings, calculated by the formula above, are presented in Table 4.

According to the integral index $C_{\mathrm{c}}$, the examined surfactants can be placed by the degree of reduction of toxicity in the following order: sodium lauryl sulfate - sodium laurate sulfate - cocamidopropylbetaine - sodium salt of polyethoxysulfosuccinate - alkyldimethyl betaine - disodium cocoamphodiacetate - sodium salt of n-palmitylglutamic acid - cocoglucoside - diethanolamides of fatty acids of coconut oil - polyquaternium 7 . 
Table 4: Values of surfactant cytotoxicity integral index

\begin{tabular}{|c|c|}
\hline Surfactant & Integral index of surfactant cytotoxicity $C_{\mathrm{c}}$ (conv. un.) \\
\hline \multicolumn{2}{|c|}{ Anionic surfactants } \\
\hline Sodium lauryl sulfate & $0.09 \pm 0.0006$ \\
\hline Sodium laurate sulfate & $0.13 \pm 0.0009$ \\
\hline Sodium salt of polyethoxysulfosuccinnate & $0.78 \pm 0.0012$ \\
\hline \multicolumn{2}{|c|}{ Amphoteric surfactant } \\
\hline Cocamidopropylbetaine & $0.27 \pm 0.0015$ \\
\hline Disodium cocoamphodiacetate & $1.99 \pm 0.0019$ \\
\hline Alkyldimethylbetaine & $1.07 \pm 0.0023$ \\
\hline Sodium salt of n-palmitylglutamic acid & $3.22 \pm 0.0002$ \\
\hline \multicolumn{2}{|c|}{ Nonionic surfactants } \\
\hline Cocoglucoside & $27.6 \pm 0.0012$ \\
\hline Diethanol amides of fatty acids of coconut oil & - \\
\hline \multicolumn{2}{|c|}{ Cationic surfactants } \\
\hline
\end{tabular}

\section{Conclusions}

Analysis and generalization of study results, conducted by the Method of the Assessment of the Cytotoxic Effect of the Agents Based on the Surfactants, show that this method makes it possible to detect the degree of cytotoxic effect of the surfactants. The anionic and amphoteric surfactants were the most aggressive components and nonionic surfactants had a much lower cytotoxic effect (10 times less).

Taking into account a different degree of cytoxicity of studied substances, the manufacturers of cleansings that seek to create the "soft" special- purpose products, for example, such as cleanings for children's skin and hair, intimate hygiene, washing of children's dishes, may be recommended to introduce less cytotoxic substances in terms of $C_{\mathrm{c}}$ into the formulations or to reduce the percentage of anionic surfactants (or remove them) by increasing nonionic and "soft" amphoteric surfactants.

In the future, we plan to develop a comprehensive program for the study of the safety of surfactants using the Method for the Assessment of the Cytotoxic Effect of the Agents Based on Surfactants at the screening stage.

\section{References}

[1] Khamidulina KhKh. Main trends of the international activities in the sphere of chemical safety and their implementation in the Russian Federation. Toxicol Rev. 2011;6:2-7.

[2] Timofeiev G. Safety and efficacy on the way of cosmetic products to the costumers. SORF J. 2007;5:34-40.

[3] Ernandes YI, editor. New cosmetology. Vol I. Moscow: Klavel Ltd.; 2005. 424 p.

[4] Ernandes YI, Margolina A, Petruhina A. Lipid barrier of skin and cosmetics. Moscow: Klavel Ltd.; 2003. 340 p.

[5] Corazza M, Laurla MM, Zappaterra M, Bianchi A, Virgili A. Surfactants, skin cleansing protagonists. J Eur Acad Dermatol Venerol. 2010;24(1):1-6. DOI: 10.1111/j.1468-3083.2009.03349.X

[6] Voloschenko OI, Raietska OV, Yalovenko OI, Kyzmina AI. Method for the estimation of cytotoxic effect of the agents on the basis of surfactants. of Ukraine Patent 28727. 2007 Dec 25.

[7] Voloschenko OI, Raietska OV, Yalovenko OI. The current state of the alternative modeling of the assessment of skin irritation (review). Environment and Health. 2008; 3:67-71.

[8] Hatao M, Murakami N, Sakamoto K, Ohnuma M, Matsushige C, Kakishima H, et al. Interlaboratory Validation of the in vitro Eye IrritationTests for Cosmetic Ingredients. (4) Hemoglobin Denaturation Test. Toxicol in vitro. 1999;13(1):125-37. DOI: $10.1016 /$ S0887-2333(98)00067-8

[9] Antomonov M. Mathematical processing and analysis of biomedical data. 2nd ed. Kyiv: Medinform; 2018. 579 p.

[10] Pletniov MJ. Surfactants and compositions. Moscow: Klavel Ltd.; 2002. 768 p. 


\section{О.І. Яловенко, О.В. Раєцька, О.М. Голіченков, В.І. Ляшенко, О.М. Дуган}

\section{СУСПЕНЗІЙНА КУЛЬТУРА ЕРИТРОЦИТІВ У ОЦІНЦІ СТУПЕНЯ ТОКСИЧНОСТІ ФУНКЦІОНАЛЬНИХ КОМПОНЕНТІВ МИЙНИХ ТА ОЧИСНИХ ЗАСОБІВ}

Проблематика. Дослідження присвячено оцінці цитотоксичних властивостей різних поверхнево-активних речовин (ПАР) методом, який є високочутливим до виявлення їх негативний впливу на живі клітини ссавців.

Мета. Провести порівняльну оцінку сучасних ПАР за ступенем виявленості цитотоксичних властивостей.

Методика реалізації. Дослідження 10 ПАР проводили новим способом оцінки цитотоксичної дії засобів на основі поверхневоактивних речовин, який є модифікацією The RBC Hemolysis Test i Hemoglobin Denaturation Test. За цим способом обчислюється інтегральний показник цитотоксичності $\left(K_{c}\right)$, який враховує дані, отримані двома тестами. В роботі визначено 3 показники: відсоток денатурації гемоглобіну в $1 \%$-ному розчині ПАР $(D, \%)$, концентрацію розчину ПАР, за якої настає гемоліз $50 \%$ еритроцитів $\left(\mathrm{H}_{50}, \%\right)$, і коефіцієнт цитотоксичності ПАР (K, умов. од.), який обчислюється за фрормулою $K_{\mathrm{c}}=\mathrm{H}_{50} / \mathrm{D} \cdot 10000$.

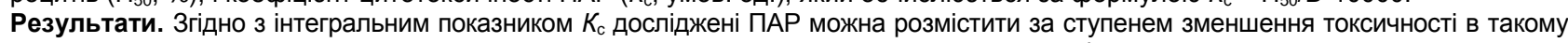
порядку: лаурилсульфат натрію $(0,09)$ - лауретсульфат натрію $(0,13)$ - кокамідопропілбетаїн $(0,27)$ - натрієва сіль поліетоксисульфосукцинату $(0,27)$ - алкілдиметилбетаїн $(1,07)$ - динатрій кокоамфодіацетат $(1,99)$ - натрієва сіль n-пальметил глютамінової кислоти $(3,22)$ - кокоглюкозид $(27,86)$. Діетаноламіди жирних кислот кокосової олії та полікватерніум 7 у дослідженому діапазоні концентрацій (до 1 \%) не виявили денатураційних властивостей.

Висновки. Проведені дослідження показали, що за рівнем пошкоджуючої дії сурфактанти значно різняться між собою, найбільш агресивними компонентами виявились аніонні й амфотерні ПАР, і значно меншу цитотоксичну дію (в 10 разів) мають неіонні ПАР. Враховувати отримані результати необхідно при створенні м'яких засобів на основі ПАР.

Ключові слова: денатурація гемоглобіну; гемоліз еритроцитів; аніонні поверхнево-активні речовини; амфотерні поверхневоактивні речовини; неіонні поверхнево-активні речовини; токсичність; пошкоджуюча дія.

\section{СУСПЕНЗИОННАЯ КУЛЬТУРА ЭРИТРОЦИТОВ В ОЦЕНКЕ СТЕПЕНИ ТОКСИЧНОСТИ ФУНКЦИОНАЛЬНЫХ КОМПОНЕНТОВ МОЮЩИХ И ОЧИЩАЮЩИХ СРЕДСТВ}

Проблематика. Исследование посвящено оценке цитотоксических свойств разных поверхностно-активных веществ (ПАВ) методом, который является высокочувствительным к выявлению их негативного влияния на живые клетки млекопитающих. Цель. Провести сравнительную оценку современных ПАВ по степени проявления цитотоксических свойств.

Методика реализации. Исследование 10 ПАВ проводили новым способом оценки цитотоксического действия средств на основе поверхностно-активных веществ, который является модификацией The RBC Hemolysis Test и Hemoglobin Denaturation Test. По этому способу рассчитывается интегральный показатель цитотоксичности, который учитывает данные, полученные двумя тестами. В работе определены показатели: процент денатурации гемоглобина в 1 \%-ном растворе ПАВ ( $D$, \%), концентрация раствора ПАВ, при которой наступает гемолиз 50 \% еритроцитов $\left(\mathrm{H}_{50}, \%\right)$, и коэффиццент цитотоксичности (К который вычисляется по формуле $K_{\mathrm{c}}=\mathrm{H}_{50} / D \cdot 10000$.

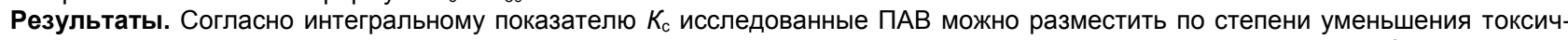
ности в следующем порядке: лаурилсульфат натрия $(0,09)$ - лауретсульфат натрия $(0,13)-$ кокамидопропилбетаин $(0,27)$ натриевая соль полиетоксисульфосукцината $(0,27)$ - алкилдиметилбетаин $(1,07)$ - динатрий кокоамфодиацетат $(1,99)$ натриевая соль n-пальметилглютаминовой кислоты $(3,22)$ - кокоглюкозид $(27,86)$. Диетаноламиды жирных кислот кокосового масла и поликватерниум 7 в исследованном диапазоне концентраций (до 1 \%) не проявили денатурационных свойств.

Выводы. Проведенные исследования показали, что по уровню повреждающего действия ПАВ значительно отличаются между собой, наиболее агрессивными компонентами оказались анионные и амфотерные ПАВ, значительно меньшее цитотоксическое действие (в 10 раз) имеют неионные ПАВ. Учитывать полученные результаты необходимо при создании мягких средств на основе ПАВ.

Ключевые слова: денатурация гемоглобина; гемолиз эритроцитов; анионные поверхностно-активные вещества; амфотерные поверхностно-активные вещества; неионные поверхностно-активные вещества; токсичность; повреждающее действие. 